\title{
Investigation of the Coping Styles of University Students With Stress According to the Social Skill Levells and Perception of Happiness
}

\section{T. Fikret KARAHAN* ${ }^{*}$ Abdullah N. DİCLE ${ }^{* *}$, Hatice EPLIKKOÇ**}

\begin{abstract}
In this study differentiation of the coping styles of the university students with stress have been investigated according to the social skill levels and perception of happiness. The sample consists of 1276 university students. Coping styles of the university students with stress have been measured by 'Coping Styles of Stress Scale', which was adopted to Turkish by Şahin and Durak (1995), and social skill levels have been measured by 'Social Skill Inventory', which was adopted to Turkish by Yüksel (2000). In addition, students' perception of happiness has been tested with Personal Information Form. In analyzing the data, one way Anova, t-test, and LSD test techniques have been used. The findings of the study have revealed that the students who have low levels of social skill and the students who feel unhappy in general use self-hopelessness approach to cope with stress $(\mathrm{p}<0.001)$. The students who have high levels of social skill levels and the students who feel happy in general use more selfreliance approach to cope with stress $(\mathrm{p}<0.001)$. In the study, it has also been determinated that the social skill levels of happy students are higher than those of unhappy students $(\mathrm{p}<0.001)$. As a result, it

\footnotetext{
Assistant Professor Dr., Ondokuz Mayls University, Department of Psychological Counseling and Guidance. <tfikretkarahan@ hotmail.com>

Research Assistant., Ondokuz Mayls University, Faculty of Education Department of Psychological Counseling and Guidance.<andicle@yahoo.com>, <eplikoc@hotmail.com>
} 
can be put forward that students who have low levels of social skills, and unhappy students feel helpless and weak in coping with stress, and they need a psychological support.

Key Words: Social Skill, Coping Styles of Stress, Self-Reliance Approach, Self-Hopelessness Approach, Happiness Perception.

\section{SUMMARY}

In this study differentiation of the coping styles of the university students with stress has been investigated according to the social skill levels and perception of happiness. According to the findings it can be put forward that low social skill levels and perception of unhappiness have detrimental effects on the use of the problem focused techniques for coping strategies with stress. The sample consists of 1276 university students. Coping styles of the university students with stress have been measured by Coping Styles of Stress Scale which was adopted to Turkish by Şahin and Durak (1995); social skill levels were measured by Social Skill Inventory which was adopted to Turkish by Yüksel (2000). In addition, student's perception of happiness and unhappiness has been tested with Personal Information Form. It can also be put forward that low social skill levels cause unhappiness in terms of human relations and communication skills. It has been found out that social skill levels of $\% 13$ of students are low, \% 18 of students are high, and \% 68 of students are at the moderate level. It is expected that mostly university students have high social skill levels. However, as can be seen, the results are in contradictory with this expectation. It can be pointed out that mostly university students need support in social skill training program. One way Anova, t-test, and LSD test techniques have been used in analyzing the data.

According to this point, it can be stated that social skill has an important effect on coping with stress in terms of personality. When the long-term effect of stress is considered, it can be put forward that individuals who have high levels of social skill endure the stress resources. On the other hand individuals who have low levels of social skill use some insufficient techniques with coping stress, such as aggressive behaviours, substance abuse, introversive behaviors, suicade, depression and another mental disorders and some defense mechanizm.

It can also be put forward that using social skills with the highest level in social relations have important effect in adoptation process. It can be pointed out that individuals who have high social skill levels use some effective techniques for the stres resource. These are; progressing the communication and problem solving skills, performing confidential behaviors, gaining social support, and learning the sharing of emotions. In other words these individuals use effective techniques for coping with stress. 


\section{Üniversite Öğrencilerinin Stresle Başaçıkma Tarzlarının Sosyal Beceri Düzeylerine ve Mutluluk Algılarına Göre İncelenmesi}

\section{T. Fikret KARAHAN* , Abdullah N. DİCLE ${ }^{* *}$, Hatice EPLIKOÇ***}

ÖZ. Bu araştırmada üniversite öğrencilerinin stresle başaçıkma tarzlarının, sosyal beceri düzeylerine ve mutluluk algılarına göre anlamlı düzeyde değişip değişmediği incelenmiştir. Araştırmanın örneklemi Küme Örnekleme Yöntemi kullanılarak belirlenmiş olup örneklem toplam 1276 öğrenciden oluşmaktadır. Öğrencilerin stresle başaçıkma tarzları, Şahin ve Durak (1995) tarafindan Türkiye uyarlaması yapılan Stresle Başaçıkma Tarzları Ölçeği ile; sosyal beceri düzeyleri ise Türkiye uyarlaması Yüksel (2000) tarafindan yapılan Sosyal Beceri Envanteri ile ölçülmüsşür. Araştırmada ayrıca öğrencilerin kendilerini mutlu hissedip hissetmediklerini belirlemek amacıyla Kişisel Bilgi Formu kullanılmıştır. Verilerin analizinde Tek Yönlü Varyans Analizi, t-testi ve LSD Testi teknikleri kullanılmıştır. Araştırmada elde edilen bulgular; sosyal beceri düzeyi düşük olan ögrencilerle kendini genel olarak mutsuz hisseden öğrencilerin stresle başaçıkmada çaresiz yaklaşımı daha çok kullandıklarını $(p<0.001)$ göstermektedir. Sosyal beceri düzeyi yüksek olan öğrencilerle kendini genel olarak mutlu hisseden öğrencilerin stresle başaçıkmada kendine

\footnotetext{
"Yrd. Doç. Dr., Ondokuz Mayıs Üniversitesi Eğitim Fakültesi, Eğitim Bilimleri Bölümü Psikolojik Danışma ve Rehberlik Anabilim Dalı, Kurupelit/Samsun. <tfikretkarahan@hotmail.com>

** Arş. Gör., Ondokuz Mayıs Üniversitesi Eğitim Fakültesi Psikolojik Danışma ve Rehberlik Anabilim Dal1, Kurupelit/Samsun. <andicle@yahoo.com>; <eplikoc@hotmail.com>
} 
güvenli yaklaşımı daha çok kullandıkları $(\mathrm{p}<0.001)$ saptanmıştır. Araştırmada ayrıca kendini mutlu hisseden öğrencilerin sosyal beceri düzeylerinin, kendini mutsuz hisseden öğrencilere göre daha yüksek olduğu ( $p<0.001)$ görülmüştür. Sonuç olarak sosyal beceri düzeyi düşük olan ve kendini mutsuz hisseden öğrencilerin, stresle başaçıkmada kendilerini daha güçsüz ve çaresiz hissettikleri ve psikolojik yardıma daha çok ihtiyaç duydukları ileri sürülebilir.

Anahtar Sözcükler: Sosyal Beceri, Stresle Başaçıkma Tarzı, Kendine Güvenli Yaklaşım, Çaresiz Yaklaşım, Mutluluk Algısı.

\section{GİRIŞ}

Sosyal beceriler, çocukluk yıllarından itibaren gerçekleşen olumlu ya da olumsuz yaşantılar sonucunda kazanılmakta olup (Cartledge \& Milburn,1992), ergenlik ve yetişkinlik yıllarında bireyin okul (Wilson, 2002), aile ve iş yaşamını da yakından etkilemektedir (Kelly, 1982). Sosyal beceriler, bireyin içinde bulunduğu gelişim dönemine, cinsiyete ve sosyal statüye göre ve kimi zaman da kültürden kültüre farklllık gösterebilmektedir (Fontana, 1992). Genel olarak ele alındığında sosyal beceri, toplum tarafından kabul gören, bireylerin amaçlarına ulaşmak ve diğer bireylerden destek alabilmek için başka bireylerle ilişki kurarak olumlu tepkiler almasını sağlayan ve olumsuz tepkiler almasını engelleyen öğrenilmiş beceriler olarak tanımlanmaktadır (Kelly, 1982; Cartledge \& Milburn,1992).

Spence (2003), sosyal beceriyi bireyin toplumsal yaşamda başarılı olabilmesi için gerekli olan davranışları sergileme becerisi olarak tanımlamakta, sözel olan ve sözel olmayan tepkiler olarak ikiye ayırmaktadır. Sözel olmayan tepkileri göz teması, yüz ifadesi, beden duruşu ve sosyal mesafe olarak; sözel olan tepkileri ise ses tonu, sesin yüksekliği, konuşmanın akıcılığı ve anlaşılabilirliği olarak açıklamaktadır. Trower da (1980), sosyal beceriyi içerik ve süreç olmak üzere iki boyuta ayırarak incelemektedir. Sosyal becerinin içeriğinde bakışlar ve baş sallama gibi sosyal ilişki sırasında sergilenen davranışlar yer almaktadır. Süreç olarak sosyal beceri ise bireyin bazı kurallara ve amaçlara göre başka bireylerden geri bildirim almak için kullandığı becerilerden oluşmaktadır (Akt: Cartledge \& Milburn, 1992). Sosyal becerinin içeriğini oluşturan davranışlar ise; kişilerarası iletişimde kullanılan sözcükler, ifadeler ve mimiklerden oluşmaktadır (Abbott \& Lewry, 1992).

Riggio (1986), temel sosyal becerileri anlatımc1lı ve duyarlık boyutları altında; duyuşsal anlatımcılık, duyuşsal duyarlık, sosyal anlatımcılık ve sosyal duyarlık olarak sıralamaktadır. Duyuşsal anlatımcılık, kişiler arası iletişimde başkalarını etkilemeyi ve bu doğrultuda sergilenen tutumları; duyuşsal duyarlık, karşıdaki bireylerin duygularını, düşüncelerini ya da tutumlarını anlama becerilerini içermektedir. Sosyal anlatımcılık sözel ifade, 
sözel akıcılık, karşılıklı konuşabilme ve görüş alışverişinde bulunabilme becerilerini; sosyal duyarlık ise sözel mesajları alma, anlama, sosyal normları ögrenme ve buna göre davranma becerilerini içermektedir. Riggio bunlara ek olarak duyuşsal kontrol ve sosyal kontrol adını verdiği iki sosyal beceriyi bireylerin daha çok kullandığını belirtmektedir. Bu iki beceriden duyuşsal kontrolü; duyuşsal iletişimi ve sözel olmayan ifadeleri düzenleme becerisi olarak; sosyal kontrolü ise sözel davranışların düzenlenmesi ve kendini ifade becerileri olarak açıklamaktadır.

Sosyal beceriye sahip olma durumu; duyguları rahatlikla ifade edebilme, başkalarının duygularını ifade etmesine yardımcı olabilme, uygun yer ve zamanda değerlendirme yapabilme olarak açıklanabilir (Becker, Heimberg \& Bellack, 1987). Başka bir anlatımla, sosyal becerilerin yeterli olması durumunda selamlaşma, dinleme becerileri, konuşmayı başlatma ve sürdürme, davranış1 değerlendirme, duygu ve düşüncelerini paylaşma, problem çözme, oyuna katılma, özür dileme, zor durumlarla başaçıkabilme, bir isteği ifade edebilme, duygusal farkındalık, etkili soru sorma, yeni durumlara uyum sağlama, duygu ve düşüncelerini açık ve somut olarak karşıdaki bireylere yansıtma, olumlu duyguları ifade etme, kavgadan uzak durma, alay etmeye karşı koyma, çevresindeki bireylerin duygularını fark edebilme, başkalarını onaylama ve destekleme, öfke ile başetme, başkalarıyla uzlaşma, izin isteme, kendini ödüllendirme, kendini açma ve güvengenlik gibi becerilerin sergilenmesi gerekli görülmektedir. Sosyal becerilerdeki yetersizlik ise yukarıda sıralanan temel sosyal becerilerin öğrenilememiș ya da kazanılamamıș olması ve var olan becerilerin uygun ortamlarda kullanılamaması şeklinde ortaya çıkmaktadır (Hargie, 1994; Begun, 1996; Akkök, 2003).

Sosyal beceriye benzer biçimde stres karşısında gösterilen tepki de önemli bir kişilik özelliği olarak ortaya çıkmaktadır. Lazarus ve Folkman (1984), stresi bireyin iyilik ve denge durumunu tehlikeye sokarak uyumu zorlaştıran ve kapasitelerini yeterince kullanmasını engelleyen, kişi ve çevre arasındaki etkileşim olarak tanımlamaktadır. Stres kısa vadede kayg1, karamsarlık ve kızgınlık, unutkanlık, dikkati toplayamama, kan basıncında kalp vurum sayısında ve adale geriliminde artış gibi problemlere neden olabilmektedir. Uzun vadede ise kalp hastalıkları, hiper tansiyon, baş ağrısı, kronik anksiyete, depresyon, fobik bozukluklar, kişilik bozuklukları, düşünce ve bellek kusurları gibi problemlere neden olabilmekte; bireyde yakın ilişkilerden uzaklaşma, yaşamdan zevk alamama ve üretkenliğin azalması gibi sonuçlar doğurmaktadır (Baltaş \& Baltaş, 2002).

Stres, bireyin yaşam kalitesini zayıflatarak psiko-sosyal ve fizyolojik açıdan güçsüzlük yaşamasına neden olabilmektedir. Kronik stresin organizmanın psikolojik ve fiziksel sağlı̆̆ına yönelik önemli bir risk oluşturduğu düşünüldüğünde, stres kaynakları karşısında sergilenen 
başaçıkma tepkilerinin bilinçli tepkiler olması, stresin olumsuz etkilerini azaltabilmektedir. Bu nedenle stresle başaçıkma amacıyla bazı yöntemlerin kullanılmas1 gereklidir. Bunlar stresin olumsuz etkilerini daha da artıran yetersiz yöntemler ya da stresin olumsuz etkilerini azaltmaya yönelik yeterli yöntemler olabilmektedir. Yetersiz yöntemler; saldırgan davranışlar sergileme, madde kullanma, içe kapanma, intihar, depresyon ve diğer ruh hastalıkları ve çeşitli savunma mekanizmalarının kullanılması olarak sıralanabilir. Yeterli yöntemler ise nefes egzersizleri, aerobik, jimnastik, gevşeme, doğru beslenme, zamanı iyi kullanma, hayata bir bilim adamı gibi yaklaşmayı alışkanlık haline getirme, stres oluşturucu yaşantıları bir tehdit olarak yorumlamak yerine yeteneklerini, irrasyonel inançlarını ve varsayımlarını sınamayı öğrenme, duygularını başkalarıyla uygun biçimde paylaşabilmeyi öğrenme, sosyal destekten yararlanma, güvengen davranışlar geliştirme, iletişim ve problem çözme becerilerini geliştirme şeklinde sıralanabilir (Şahin, 1994).

Stres karşısında kullanılan yeterli ya da yetersiz yöntemler, başaçıkma kavramını gündeme getirmektedir. Folkman \& Lazarus (1985) başaçıkmayı, çevreden ve içten gelen istek ve çatışmaları kontrol etme ve yaşam gerilimini en az düzeye indirmek amacıyla sergilenen davranışsal ve duygusal tepkiler olarak açıklamaktadır. Başaçıkma genel olarak iki kategoride toplanmaktadır. Bunlar; probleme odaklanan başaçıkma stratejileri ve duyguya odaklanan başaçıkma stratejileridir (Carver \& Scheier, 1994; Richter \& Richter, 1991; Ptacek, Smith \& Zanas, 1992; Folkman \& Lazarus, 1996). Probleme odaklanan başaçıkma daha aktif bir strateji olup stres kaynakları karşısında bilgiye ve planlı eyleme dayanan akılcı tepkileri içermektedir. Duyguya odaklanan başaçıkma ise pasif bir strateji olup stres kaynakları karşısında oluşan duyguları ortadan kaldırmayı içermektedir. Bireylerin başaçıkma örüntülerinde her iki başaçıkma stratejisi birlikte bulunmakta ve kullanılan stratejiler bireysel özelliklere göre değişiklik gösterebilmektedir (Folkman \& Lazarus, 1980). Sosyal beceri açısından ele alındığında ise sosyal beceri düzeyleri yüksek olan bireylerin problem odaklı başaçıkmayı kullanmaya daha yatkın ya da hazır oldukları ileri sürülebilir.

Bireysel yaşam açısından önemli bir değişken olan mutluluk ise bazı özel yaşantılarda hissedilen doyum düzeyi, algılanan olumlu duygulanım durumu, bu olumlu duygulanım durumunun siklığı (Cheng \& Furnham, 2004) ve bireyin kendi yaşamını değerlendirme derecesi (Abdel-Khalek, 2006) olarak tanımlanmaktadır. Bazı araştırmacıların da mutluluk ile yaşam doyumunu eş anlamlı kelimeler olarak kullandıkları ve benzer yaşantılar olarak tanımladıkları (Peterson, Park \& Seligman, 2005; Abdel-Khalek, 2006) gözlenmektedir. Mutluluk üzerine yapılan araştırmaların ise genellikle mutluluğun kaynakları üzerine yoğunlaştığ 1 gözlenmektedir. Bu açıdan ele alındığında Grinde (2002), mutluluğun insan doğasındaki gelişmenin dolaylı 
bir sonucu olduğunu, tüm kültürlere bakıldığında mutluluğun insan yaşamının temel ve doğal amacı olduğunu belirtmektedir. Mutluluğun temel nedenleri arasında ise kültür ve sosyal çevre faktörlerinin yanında, insanın evrensel genetik yapısının da insanı mutluluk arayışına yönelttiği belirtilmektedir. Giblin de (1995) mutluluğun kaynağını tüm yaşam alanlarında ve meslek yaşantılarında, insan ilişkilerinde sağlanan başarı ve doyuma bağlamakta ancak sağlıklı insan ilişkileri becerilerinin de tek başına mutluluğun garantisi olmadığını belirtmektedir. Crossley ve Landridge (2005) ise benzer biçimde mutluluğun kaynağı olarak sosyal ilişkileri, meslek yaşantılarını ve boş zaman aktivitelerini göstermektedir. Peterson, Park ve Seligman (2005), yaşam doyumu ve mutluluğun üç farklı boyutunun bulunduğunu belirtmekte ve bunları; yaşamdan haz alma, yaşamda anlam bulma ve bir durum, kişi ya da yaşantıya yönelme, bağlanma ya da yoğunlaşma olarak sıralamaktadır. Araştırmacılara göre bu üç boyuttan her biri bireyin yaşam doyumunu belirleyebilmektedir.

$\mathrm{Bu}$ araştırmada, sosyal beceri düzeyleri yüksek olan ve kendini mutlu hisseden bireylerin stresle başaçıkmada problem odaklı yaklaşımı diğerlerine göre daha çok kullanabilecekleri düşüncesinden hareket ederek, üniversite öğrencilerinde sosyal beceri düzeylerine ve mutluluk algısına göre stresle başaçıkma tarzları incelenmiştir. Diğer yandan kendini mutlu ya da mutsuz hissettiğini belirten öğrencilerin sosyal beceri düzeylerinin ve stresle başaçıkmada çaresiz ve kendine güvenli yaklaşımlardan hangisini daha çok kullandıklarının da saptanması hedeflenmiştir. Böylece sosyal beceri düzeyi düşük olan, kendini mutsuz hisseden ve stresle başaçıkmada duygu odaklı yaklaşımları daha çok kullanan bireylere verilecek psikolojik yardım hizmetlerine $1 s ̧ 1 \mathrm{k}$ tutulması amaçlanmıştır. Yukarıda yapılan açıklamalardan da anlaşılacağı gibi literatürde stresle başaçıkmada kullanılan yaklaşımlar duygu odaklı ve problem odaklı olmak üzere iki temel gruba ayrılmaktadır. Ayrıca araştırmayı sınırlı tutma amacıyla stresle başaçıkmada problem odaklı yaklaşıma yönelik olarak "Kendine Güvenli Yaklaşım" ve duygu odaklı yaklaşıma yönelik olarak "Çaresiz Yaklaşım" alt ölçekleri kullanılmış olup diğer alt ölçekler kullanılmamıştır. Bu amaca ve yukarıda yapılan kuramsal açıklamalara dayalı olarak araştırmada şu sorulara cevap aranmıştır;

1. Sosyal beceri düzeylerine göre öğrencilerin Çaresiz Yaklaşım Alt Ölçeği puanları arasında anlamlı farklar var mıdır?

2. Sosyal beceri düzeylerine göre öğrencilerin Kendine Güvenli Yaklaşım Alt Ölçeği puanları arasında anlamlı farklar var mıdır?

3. Mutluluk algısına göre öğrencilerin Çaresiz Yaklaşım Alt Ölçeği puanları arasında anlamlı farklar var midır? 
4. Mutluluk algısına göre öğrencilerin Kendine Güvenli Yaklaşım Alt Ölçeği puanları arasında anlamlı farklar var mıdır?

5. Mutluluk algısına göre öğrencilerin Sosyal Beceri Envanteri toplam puanları arasında anlamlı farklar var mıdır?

\section{YÖNTEM}

\section{Evren}

Araştırmanın evreni, 2005-2006 öğretim yılında Ondokuz Mayıs Üniversitesi'ne bağlı fakültelerden Eğitim, Fen-Edebiyat, Mühendislik, İlahiyat, Ziraat, Tıp ve Diş Hekimliği Fakültelerinde öğrenim gören 8347'si kız, 9126's1 erkek olmak üzere toplam 17473 öğrenciden oluşmaktadır.

\section{Örneklem}

Araştırmanın örneklemi Küme Örnekleme Yöntemi (Karasar, 1986) kullanılarak belirlenmiştir. Buna göre 2005 - 2006 öğretim yılında Ondokuz Mayıs Üniversitesi'ne bağlı Eğitim (555 öğrenci), Fen-Edebiyat (319 öğrenci), Mühendislik (132 öğrenci), İlahiyat (39 öğrenci), Ziraat (82 öğrenci), Tıp (123 öğrenci) ve Diş Hekimliği (26 öğrenci) fakültelerinde 1., 2., 3., 4. sinıflarda öğrenim gören ve uygulama yapılırken sinıfta bulunan 681 'i kız, 595'i erkek toplam 1276 öğrenciden oluşmaktadır. .

\section{Veri Toplama Araçları}

Araştırmada verilerin toplanması amacıyla "Sosyal Beceri Envanteri", "Stresle Başaçıkma Tarzları Ôlçeği” ve "Kişisel Bilgi Formu” kullanılmıştır. Türkçe literatürde öğrencilerin kendilerini mutlu ya da mutsuz hissettiklerini belirlemeye yönelik herhangi bir ölçek bulunmaması nedeniyle, mutluluk algısı Kişisel Bilgi Formu'nda yöneltilen soruya verilen cevaplara göre saptanmıștır. Bu konuda İngilizce literatürde de benzer araştırmalar (AbdelKhalek, 2006) bulunmaktadır. $\mathrm{Bu}$ nedenle Kişisel Bilgi Formu'nda öğrencilere; "Genel olarak kendinizi mutlu hissediyor musunuz?" sorusu sorulmuş ve ögrencilerin verdikleri cevaplar "evet" ya da "hayır" şeklinde gruplandırılmıştır.

\section{Sosyal Beceri Envanteri (SBE)}

Riggio (1989) tarafindan geliştirilen Sosyal Beceri Envanteri'nin orijinali için test tekrar-test yöntemi ile ölçeğin bütününden elde edilen puanlara ilişkin güvenirlik katsayısı 0.94 olarak bulunmuştur. Alt ölçeklerden elde edilen güvenirlik katsayıları ise Duyuşsal Anlatımcılık için 0.81; Duyuşsal Duyarlık için 0.90; Duyuşsal Kontrol için 0.88; Sosyal Anlatımcılık için 0.96; Sosyal Duyarlık için 0.86 ve Sosyal Kontrol için 0.92 olarak hesaplanmıştır. Envanterin Cronbach Alpha güvenirlik katsayıları alt ölçekler için 0.62 ile 0.87 arasında bulunmuştur. Ortalama iç 
tutarlılık katsayısı ise erkekler için 0.84 kızlar için ise 0.80 olarak bulunmuștur. Sosyal Beceri Envanteri'nin Riggio (1989) tarafından yapılan birleştirici ve ayırt edici geçerlik çalışmalarında çeşitli ölçme araçları kriter olarak kullanılmıştır. Sosyal Beceri Envanterinin sosyal becerileri ölçebilecek derecede geçerli bir araç olduğu sonucuna varılmıştır.

Sosyal Beceri Envanteri'nin Türkiye uyarlaması Yüksel (2000) tarafından yapılmıștır. Envanterin test tekrar-test yöntemi ile hesaplanan toplam puana ilişkin güvenirlik katsayısı tüm ölçek için 0.92 olarak bulunmuştur. Alt ölçeklerden elde edilen güvenirlik katsayıları ise Duyuşsal Anlatımcılık için 0.81; Duyuşsal Duyarlık için 0.87; Duyuşsal Kontrol için 0.80; Sosyal Anlatımcılık için 0.89; Sosyal Duyarlık için 0.88 ve Sosyal Kontrol için 0.89 olarak hesaplanmıştır. Envanterin toplam puana ilişkin iç tutarlık (Cronbach Alpha) katsayısı ise 0.85 olarak bulunmuştur. Alt ölçeklere göre elde edilen iç tutarlık katsayıları ise Duyuşsal Anlatımcılık için 0.56; Duyuşsal Duyarlık için 0.80; Duyuşsal Kontrol için 0.75; Sosyal Anlatımcılık için 0.82; Sosyal Duyarlık için 0.72 ve Sosyal Kontrol için 0.81 olarak hesaplanmıştır.

Sosyal Beceri Envanteri'nin geçerlik çalışmasında kapsam ve benzer ölçekler geçerliği olmak üzere iki yöntem kullanılmıştır. Kapsam geçerliği ile ilgili çalışmada uzman kanısına başvurulmuştur. Alanda uzman olarak çalışan kişiler Sosyal Beceri Envanteri' nin bütünü ile ilgili incelemeleri sonucu, ölçeğin sosyal becerileri ölçebilecek nitelikte olduğu yönünde görüș belirtmişlerdir. $\mathrm{Bu}$ çalışmada benzer ölçekler geçerliği için Kendini Ayarlama Ölçeği kullanılmıştır. Her iki ölçekten elde edilen puanlar arasında $0.63 \quad(n=37)$ korelasyon bulunmuştur. Sosyal Beceri Envanteri'nin alt ölçekleri ile Kendini Ayarlama Ölçeği puanları arasındaki korelasyon katsayıları ise -0.21 ile 0.57 arasında değişmektedir. Sosyal Beceri Envanteri'nin bütününe ilişkin benzer ölçekler geçerlik katsayısı 0.001 düzeyinde, alt ölçeklere ilişkin katsayıları ise 0.01 düzeyinde anlamlı bulunmuştur. Sosyal Beceri Envanteri'nin her bir alt ölçeğinde 15'er madde olmak üzere, altı alt ölçekte toplam 90 madde bulunmakta, 32 madde ise tersinden puanlanmaktadır. Sosyal Beceri Envanteri'nde 5'li Likert cevaplama ölçeği kullanılmıştır. Ölçekten alınabilecek yüksek puanlar, sosyal beceri düzeyinin yüksek olduğunu, düşük puanlar ise sosyal beceri düzeyinin düşük olduğunu ifade etmektedir. Her bir alt ölçekten alınabilecek puan 15 ile 75 puan arasında, ölçeğin bütününden alınabilecek toplam puan ise 90 ile 450 puan arasında değişmektedir.

\section{Stresle Başaçıkma Tarzları Ölçeği (SBTÖ)}

Folkman ve Lazarus (1980) tarafindan geliştirilmiş olan "Stresle Başaçıkma Yolları Envanteri", stresle başaçıkma konusunun incelendiği araştırmalarda sıklıkla kullanılan, duruma yönelik ve 66 maddelik, 4'lü 
Likert tipi bir ölçektir. Türkiye'de Şahin ve Durak (1995) tarafindan üniversite öğrencilerine uyarlaması yapılan yeni adıyla "Stresle Başaçıkma Tarzları Ölçeği”" 30 maddeden oluşmaktadır. Her bir maddeye verilebilecek tepkiler, bana hiç uygun değil (\% 0); bana uygun değil (\%30); bana uygun (\%70); bana çok uygun (\%100) biçiminde dağılım göstermektedir. Ölçek; Kendine Güvenli Yaklaşım (7 Madde), İyimser Yaklaşım (5 Madde), Çaresiz Yaklaşım (8 Madde), Boyun Eğici Yaklaşım (6 Madde), Sosyal Desteğe Başvurma (4 Madde) olmak üzere toplam beş alt ölçekten oluşmaktadır. Alt ölçekler birbirinden bağımsız ve ayrı ayrı puanlanabilmektedir. Ölçekte 1. ve 9. maddeler ters puanlanmakta, diğer maddeler ise 0 ile 3 arasında puanlanmaktadır. $\mathrm{Bu}$ araştırmada "Kendine Güvenli Yaklaşım" ve "Çaresiz Yaklaşım" alt ölçekleri kullanılmıştır. Kendine Güvenli Yaklașım Alt Ölçeği'nden alınabilecek puanlar 0-21 puan arasında; Çaresiz Yaklaşım Alt Ölçeği'nden alınabilecek puanlar ise 0-24 puan arasında değişmektedir. Alt ölçeklerden alınan puanların yüksek oluşu, stresle başa çıkmada o alt ölçekteki yaklaşımın daha çok kullanıldığını göstermektedir.

Ölçeğin Şahin ve Durak (1995) tarafından yapılan güvenirlik çalışmasında, ölçek üç aşamalı faktör analizine tabi tutulmuştur. İlk faktör analizi çalışması üniversite öğrencileri üzerinde $(\mathrm{N}=575)$ Ana Eksenler (Principal Axis) yöntemiyle yapılmış ve 8 faktörlü bir yapı ortaya çıkmıştır. Aynı örneklem üzerinde Grafik Yöntemlere (Screen Test) göre yapılan faktör analizi sonucunda ise ölçeğin 5 faktöre indirgenebileceği görülmüştür. İkinci faktör analizi çalışması, özel ve kamu bankalarında çalışan $(\mathrm{N}=426)$ kişiler üzerinde Ana Eksenler Yöntemi ile yapılmış ve 7 faktörlü bir yapı ortaya çıkmıştır. Üçüncü faktör analizi çalışması ise yaşları 14-45 arasında değişen $(\mathrm{N}=232)$ kişiler üzerinde Ana Eksenler Yöntemi ile yapılmış ve öz değeri 1'in üzerinde olan beş faktör bulunmuştur. Ölçeğin üç çalışmadaki faktör analizlerine bağlı olarak elde edilen alt ölçeklerin güvenirlik katsayıları, Cronbach Alpha güvenirlik katsayısı ile saptanmış ve "İyimser Yaklaşım" alt ölçeği için elde edilen güvenirlik katsayıları $\alpha=0.68$ ile $\alpha=0.49$ arasında bulunmuştur. "Kendine Güvenli Yaklaşım" alt ölçeği için bu değer $\alpha=0.62$ ile $\quad \alpha=0.80$ arasında, "Çaresiz Yaklaşım" alt ölçeği için bu değer $\alpha=0.64$ ile $\alpha=0.73$ arasında, "Boyuneğici Yaklaşım" alt ölçeği için ise $\alpha=0.47$ ile $\alpha=0.72$ arasında bulunmuştur. Son olarak "Sosyal Desteğe Başvurma" alt ölçeği için de bu değerin $\alpha=0.47$ ile $\alpha=0.45$ arasında değiştiği saptanmıştır. Bu sonuca göre beş alt ölçeğin güvenirlik katsayılarının 0.45 ile 0.80 arasında değiştiği gözlenmiştir. Ölçeğin bütününe yönelik güvenirlik katsayısı ise 0.68 olarak saptanmıştır (Şahin ve Durak, 1995).

Ölçeğin Şahin ve Durak (1995) tarafindan yapılan geçerlik çalışmasında; psikolojik sorun belirtileriyle ilişkilerine, daha sonra çeşitli 
kişilik boyutları ve durumsal değişkenlerle ilişkileri ve farklı ölçümlere göre ayrılmış karşıt grup karşılaştırmaları yapılmıştır. Psikolojik sorunlarla ilişkiler "Sosyal Desteğe Başvurma" dışındaki tüm alt ölçekler, üç çalışmada da çeşitli belirti ölçümleriyle anlamlı ilişki içinde çıkmıştır. Ölçeğin çeşitli kişilik boyutlarıyla ilişkilerini belirleme amacıyla yapılan geçerlik çalışmasında; "Strese Yatkınlık" , "A-Tipi Kişilik" , "Genel İyimserlik", "Yaşam Doyumu" ve "Gelecekten Umut" gibi değişkenlerle ilişkilerine bakılmıştır. Strese yatkınlık puanı ile sosyal desteğe başvurma dışındaki tüm alt ölçekler arasında anlamlı korelasyonlar bulunduğu saptanmıştır. A-Tipi Kişilik açısından bakıldığında ise A-Tipi davranışlar arttıkça, iyimser ve kendine güvenli yaklaşımların azaldığı, çaresiz yaklaşımın ise arttı̆̆ saptanmıştır. Yaşam Doyumu, Genel İyimserlik ve Gelecekten Umut puanları birer kişilik boyutu olarak ele alındığında, puanlar arttıkça iyimser ve kendine güvenli yaklaşımı kullanma sıklığının arttığı; çaresiz ve boyun eğici davranışları kullanma sıklığının ise azaldığı görülmüştür. Alt ölçeklerin durumsal değişkenlerle olan ilişkisini belirleme amacıyla üç ayrı çalışma yapılmış ve sonuçta elde edilen korelasyonların anlamlı olduğu saptanmıştır. Çalışmanın son aşamasında ölçeğin geçerliğini belirleme amacıyla, Karşıt Gruplar Karşılaştırmaları yapılmıştır. $\mathrm{Bu}$ bağlamda stresle başaçıkma dereceleri değişen 4 farklı grup oluşturulmuş ve SBTÖ'nin alt ölçekleriyle ölçülmeye çalışılan başaçıkma tarzlarının bu gruplarda nasıl değiştiğine bakılmıştır. Bu amaçla yapılan Tek Yönlü Varyans Analizi sonucunda "Sosyal Desteğe Baş Vurma" dıșındaki tüm alt ölçeklerde gruplar arasında anlamlı farklılıklar bulunmuştur. Sonuç olarak elde edilen bulgular SBTÖ'nin alt ölçeklerinin etkili ve etkisiz olmak üzere iki boyutta toplandığını; bu iki alt boyutun ise kendi içinde "Kendine Güvenli Yaklaşım", "İyimser Yaklaşım", "Çaresiz Yaklaşım", "Boyun Eğici Yaklaşım" ve "Sosyal Desteğe Başvurma" olmak üzere beş alt boyuta ayrıştırılabileceğini göstermiştir.

\section{Verilerin Toplanması ve Analizi}

Araştırmada kullanılan "Sosyal Beceri Envanteri”, "Stresle Başaçıkma Tarzları Ölçeği" ve "Kişisel Bilgi Formu", örnekleme alınan öğrencilere araştırmacılar tarafindan ders saatlerinde uygulanmıştır. Uygulama öncesinde öğrencilere ölçeklerin nasıl cevaplanacağı konusunda açıklama yapılmıştır. Uygulama sonrasında ölçeklerden elde edilen veriler, istatistiksel işlem yapılmak üzere bilgisayar ortamına aktarılmıştır. Verilerin analizinde SPSS 11.0 paket programı kullanılmış olup, Tek Yönlü Varyans Analizi, ttesti ve LSD (Least-Significance Difference) tekniklerinden yararlanılmıştır. Sonuçların yorumlanmasında ise 0.05 anlamlılık düzeyi üst değer olarak alınmıştır. 


\section{BULGULAR}

Bu bölümde Ondokuz Mayıs Üniversitesi'ne bağlı çeşitli fakültelerde öğrenim gören öğrencilerin sosyal beceri düzeylerine ve mutluluk algısına göre stresle başaçıkma tarzlarının anlamlı düzeyde değişip değişmediğine ilişkin bulgulara yer verilmiştir.

\section{Sosyal Beceri Düzeylerine Göre Çaresiz Yaklaşım Alt Ölçeği Puanlarına İlişsin Bulgular}

Örneklemde yer alan öğrencilerin sosyal beceri düzeylerine göre Çaresiz Yaklaşım Alt Ölçeği (ÇYAÖ) puanlarının ortalamaları arasındaki farklılığın anlamlı olup olmadığını test etmek amacıyla veriler üzerinde Tek Yönlü Varyans Analizi uygulanmış ve sonuç Tablo - 1'de verilmiştir.

Tablo - 1. Öğrencilerin Sosyal Beceri Düzeylerine Göre Çaresiz Yaklaşım Alt Ölçeği Puanlarına İlişkin Tek Yönlü Varyans Analizi Sonuçları

\begin{tabular}{|c|c|c|c|c|c|c|c|c|c|}
\hline $\begin{array}{l}\text { Sosyal } \\
\text { Beceri } \\
\text { Düzeyi }\end{array}$ & $\mathrm{n}$ & $\begin{array}{c}\text { ÇYAÖ } \\
\text { Puanlarının } \\
\text { Ortalamaları } \\
\overline{\mathbf{X}}\end{array}$ & Ss & Kaynak & KT & $\mathrm{Sd}$ & $\mathrm{KO}$ & $\mathrm{F}$ & Sonuç \\
\hline Düşük & 165 & 13.63 & 4.15 & $\begin{array}{c}\text { Gruplar } \\
\text { Aras1 }\end{array}$ & 1231.57 & 2 & 615.78 & 32.63 & \multirow{4}{*}{$\mathrm{P}<.001$} \\
\hline Orta & 873 & 10.74 & 4.33 & $\begin{array}{l}\text { Gruplar } \\
\text { İçi }\end{array}$ & 24022.70 & 1273 & \multirow[t]{2}{*}{18.87} & & \\
\hline Yüksek & 238 & 10.59 & 4.51 & Toplam & 25254.27 & 1275 & & & \\
\hline Toplam & 1276 & & & & & & & & \\
\hline
\end{tabular}

Tablo - 1'de yer alan istatistiksel veriler, sosyal beceri düzeyi düşük, orta ve yüksek olan öğrencilerin Çaresiz Yaklaşım Alt Ölçeği puanlarının ortalamaları arasındaki farklılığı 0.001 düzeyinde anlamlı olduğunu göstermektedir. Uygulanan LSD testi sonuçları ise bu anlamlı farklılığın, sosyal beceri düzeyi Düşük-Orta ve Düşük-Yüksek olan grupların ÇYAÖ puanlarının ortalamaları arasındaki farklılıktan kaynaklandığını göstermektedir.

2. Sosyal Beceri Düzeylerine Göre Kendine Güvenli Yaklaşım Alt Ölçeği Puanlarına İlişsin Bulgular

Örneklemde yer alan öğrencilerin sosyal beceri düzeylerine göre Kendine Güvenli Yaklaşım Alt Ölçeği (KGYAÖ) puanlarının ortalamaları arasındaki farklılığın anlamlı olup olmadığını test etmek amacıyla veriler üzerinde Tek Yönlü Varyans Analizi uygulanmış ve sonuç Tablo - 2'de verilmiştir. 
Tablo - 2. Öğrencilerin Sosyal Beceri Düzeylerine Göre Kendine Güvenli Yaklaşım Alt Ölçeği Puanlarına İlişsin Tek Yönlü Varyans Analizi Sonuçları

\begin{tabular}{|c|c|c|c|c|c|c|c|c|c|}
\hline $\begin{array}{l}\text { Sosyal } \\
\text { Beceri } \\
\text { Düzeyi }\end{array}$ & $\mathrm{n}$ & $\begin{array}{c}\text { KGYAÖ } \\
\text { Puanlarının } \\
\text { Ortalamaları } \\
\overline{\mathbf{X}} \\
\end{array}$ & Ss & Kaynak & KT & $\mathrm{Sd}$ & $\mathrm{KO}$ & $\mathrm{F}$ & Sonuç \\
\hline Düşük & 165 & 8.44 & 2.45 & $\begin{array}{c}\text { Gruplar } \\
\text { Arası }\end{array}$ & 5539.08 & 2 & 2769.54 & 278.18 & \multirow{4}{*}{$\mathrm{P}<.001$} \\
\hline Orta & 873 & 14.46 & 3.21 & $\underset{\text { İçi }}{\text { Gruplar }}$ & 12673.89 & 1273 & 9.95 & & \\
\hline Yüksek & 238 & 15.13 & 3.35 & Toplam & 18212.98 & 1275 & & & \\
\hline Toplam & 1276 & & & & & & & & \\
\hline
\end{tabular}

Tablo - 2'de yer alan istatistiksel veriler, sosyal beceri düzeyi düşük, orta ve yüksek olan öğrencilerin Kendine Güvenli Yaklaşım Alt Ölçeği puanlarının ortalamaları arasındaki farklılığın 0.001 düzeyinde anlamlı olduğunu göstermektedir. Uygulanan LSD testi sonucunda ise bu anlamlı farklılığın; sosyal beceri düzeyi Düşük-Orta, Düşük-Yüksek ve OrtaYüksek olan grupların KGYAÖ puanlarının ortalamaları arasındaki farklılıktan kaynaklandığ 1 saptanmıştır.

3. Mutluluk Algısına Göre Çaresiz Yaklaşım Alt Ölçeği Puanlarına İlişkin Bulgular

Araştırmada örneklemde yer alan öğrencilerin kendilerini genel olarak mutlu ya da mutsuz hissettiklerini belirleme amaciyla Kişisel Bilgi Formu'nda; "Genel olarak kendinizi mutlu hissediyor musunuz?" sorusu sorulmuş ve öğrencilerin verdikleri cevaplar "evet" ya da "hayır" şeklinde gruplandırılmıştır. Kendini mutlu ve mutsuz hisseden öğrencilerin Çaresiz Yaklaşım Alt Ölçeği puanlarının ortalamaları arasındaki farklılığın anlamlı olup olmadığını test etmek amacıyla veriler üzerinde t-testi uygulanmış ve sonuç Tablo - 3’te verilmiştir.

Tablo - 3. Mutluluk Algısına Göre Çaresiz Yaklaşım Alt Ölçeği Puanlarına İlişskin t-testi Sonuçları

\begin{tabular}{ccccccc}
\hline $\begin{array}{c}\text { Mutluluk } \\
\text { Algısı }\end{array}$ & $\mathrm{n}$ & $\begin{array}{c}\text { ÇYAÖ } \\
\text { Puanlarının } \\
\text { Ortalamaları } \\
\overline{\mathbf{X}}\end{array}$ & Ss & Sd & t & Sonuç \\
\hline Mutluyum & 902 & 10.45 & 4.30 & 1274 & 8.12 & \\
$\begin{array}{c}\text { Mutsuzum } \\
\text { Toplam }\end{array}$ & 374 & 12.62 & 4.43 & & & $\mathrm{P}<.001$ \\
\hline
\end{tabular}


Tablo - 3'te yer alan istatistiksel veriler, kendini genel olarak mutlu ve mutsuz algılayan öğrencilerin Çaresiz Yaklaşım Alt Ölçeği puanlarının ortalamaları arasındaki farklılığın 0.001 düzeyinde anlamlı olduğunu göstermektedir. Elde edilen bu sonuca göre, kendini mutsuz hisseden öğrencilerin stresle başaçıkmada çaresiz yaklaşımı kendini mutlu hissedenlere göre daha çok kullandıkları ileri sürülebilir.

\section{Mutluluk Algısına Göre Kendine Güvenli Yaklaşım Alt Ölçeği Puanlarına İlişkin Bulgular}

Kendini mutlu ve mutsuz hisseden öğrencilerin Kendine Güvenli Yaklaşım Alt Ölçeği puanlarının ortalamaları arasındaki farklılığın anlamlı olup olmadığını test etmek amacıyla veriler üzerinde t-testi uygulanmış ve sonuç Tablo - 4'te verilmiştir.

Tablo - 4. Mutluluk Algısına Göre Kendine Güvenli Yaklaşım Alt Ölçeği Puanlarına İlişkin t-testi Sonuçları

\begin{tabular}{ccccccc}
\hline $\begin{array}{c}\text { Mutluluk } \\
\text { Algısı }\end{array}$ & $\mathrm{n}$ & $\begin{array}{c}\text { KGYAÖ } \\
\text { Puanlarının } \\
\text { Ortalamaları }\end{array}$ & Ss & Sd & t & Sonuç \\
\hline Mutluyum & 902 & 14.73 & 3.41 & 1274 & 14.61 & \\
$\begin{array}{c}\text { Mutsuzum } \\
\text { Toplam }\end{array}$ & 374 & 11.59 & 3.70 & & & $\mathrm{P}<.001$ \\
\hline
\end{tabular}

Tablo - 4'te yer alan istatistiksel veriler, kendini genel olarak mutlu ve mutsuz algılayan öğrencilerin Kendine Güvenli Yaklaşım Alt Ölçeği puanlarının ortalamaları arasındaki farklılığın 0.001 düzeyinde anlamlı olduğunu göstermektedir. Elde edilen bu sonuca göre, kendini mutlu hisseden öğrencilerin stresle başaçıkmada kendine güvenli yaklaşımı kendini mutsuz hissedenlere göre daha çok kullandıkları ileri sürülebilir.

\section{Mutluluk Algısına Göre Sosyal Beceri Envanteri Toplam Puanlarına İlişkin Bulgular}

Kendini mutlu ve mutsuz hisseden öğrencilerin Sosyal Beceri Envanteri toplam puanlarının ortalamaları arasındaki farklılı̆̆ın anlamlı olup olmadığını test edebilme amacıyla, veriler üzerinde t-testi uygulanmış ve sonuç Tablo - 5'te verilmiştir. 
Tablo - 5. Mutluluk Algisina Sosyal Beceri Envanteri Toplam Puanlarına İliş kin t-testi Sonuçları

\begin{tabular}{|c|c|c|c|c|c|c|}
\hline $\begin{array}{l}\text { Mutluluk } \\
\text { Algis1 }\end{array}$ & $\mathrm{n}$ & $\begin{array}{c}\text { Sosyal Beceri } \\
\text { Envanteri Toplam } \\
\text { Puanlarının } \\
\text { Ortalamaları } \\
\overline{\mathbf{X}} \\
\end{array}$ & Ss & $\mathrm{Sd}$ & $\mathrm{t}$ & Sonuç \\
\hline $\begin{array}{c}\text { Kendimi } \\
\text { Mutlu } \\
\text { Hissediyorum }\end{array}$ & 902 & 314.75 & 61.97 & 1274 & 13.51 & \multirow{3}{*}{$\mathrm{P}<.001$} \\
\hline $\begin{array}{l}\text { Kendimi } \\
\text { Mutsuz } \\
\text { Hissediyorum }\end{array}$ & 374 & 256.30 & 87.33 & & & \\
\hline Toplam & 1276 & & & & & \\
\hline
\end{tabular}

Tablo - 5'te yer alan istatistiksel veriler, kendini genel olarak mutlu ve mutsuz algılayan öğrencilerin Sosyal Beceri Envanteri toplam puanlarının ortalamaları arasındaki farklılığı 0.001 düzeyinde anlamlı olduğunu göstermektedir. Elde edilen bu sonuca göre, kendini mutsuz hisseden öğrencilerin sosyal beceri düzeylerinin kendini mutlu hisseden öğrencilere göre daha düşük olduğu ileri sürülebilir.

\section{TARTIŞMA VE YORUM}

$\mathrm{Bu}$ araştırmada, üniversite öğrencilerinin sosyal beceri düzeylerine ve mutluluk algılarına göre stresle başaçıkma tarzları incelenmiştir. Araştırmada elde edilen bulgular; sosyal beceri düzeyleri yüksek olan ve ayrıca kendini mutlu hisseden öğrencilerin stresle başaçıkmada problem odaklı yaklaşımı daha çok kullandıklarını göstermektedir. Sosyal beceri düzeyi düşük olan ve ayrıca kendini mutsuz hisseden öğrencilerin ise stresle başaçıkmada çaresiz yaklaşımı daha çok kullandıkları saptanmıştır. Araştırmada ayrıca kendini mutsuz hisseden öğrencilerin sosyal beceri düzeylerinin, kendini mutlu hisseden öğrencilere göre daha düşük olduğu saptanmıştır. Elde edilen bulgulara göre düşük sosyal beceri düzeyi ve mutsuzluk algısının, stresle başaçıkmada etkili olan problem odaklı başaçıkma stratejisini kullanma açısından engel oluşturduğu ileri sürülebilir. Diğer yandan düşük sosyal beceri düzeyinin, insan ilişkileri ve iletişim becerileri açısından mutsuzluğa zemin hazırladığı ileri sürülebilir. Örneklemde yer alan öğrencilerin \% 13'ünün sosyal beceri düzeylerinin düşük, \% 18'inin de sosyal beceri düzeylerinin yüksek olduğu, yığılmanın $\% 68$ 'lik bir oran ile orta düzeyde yoğunlaştığı gözlenmektedir. Üniversite öğrencilerinde sosyal beceri düzeyleri açısından yığılmanın yüksek düzeyde olması beklenmekteydi ancak elde edilen bu sonucun dikkat çekici ve düşündürücü olduğunu vurgulamak gerekir. $\mathrm{Bu}$ durum, örneklemde yer alan 
öğrencilerin büyük çoğunluğunun temel sosyal beceriler açısından problem yaşadıklarını ve sosyal beceri eğitimine ihtiyaç duyduklarını göstermektedir.

Literatür incelendiğinde, sosyal beceri konusunda yapılan araştırmalarda sosyal beceri düzeyi düşük olan bireylerin insan ilişkilerinde daha başarısız oldukları ve empatik beceri düzeylerinin diğerlerine göre daha düşük olduğu (Segrin, 2001; Riggio, Joan, \& David, 1989), yalnızlık düzeylerinin diğerlerine göre daha yüksek olduğu (Hamarta, 2000), bağımlı kişilik yapısı sergiledikleri ve diğerlerine göre depresyon düzeylerinin daha yüksek olduğu (Huprich, Clancy, Bornstein, \& Nelson-Gray, 2004) rapor edilmektedir. Diğer yandan, sosyal beceri düzeyi düşük olan bireylerin kaygı ve saldırganlık düzeylerinin diğerlerine göre daha yüksek, benlik saygısı düzeylerinin ise daha düşük olduğu (Harman, Hansen, Cochran, \& Lindsey, 2005; Fox \& Boulton, 2005), ergen ve yetişkinlere benzer olarak sosyal beceri düzeyi düşük olan ilköğretim öğrencilerinin de okul uyumlarının düşük ve depresyon düzeylerinin yüksek olduğu (Uz Baş, 2003) belirtilmektedir. Burada sıralanan değişkenler açısından değerlendirildiğinde, sosyal beceri düzeyi düşük olan bireylerin stresle başaçıkmada diğer bireylere göre daha dirençsiz ve güçsüz durumda oldukları ve mutsuzluğa daha yatkın oldukları ileri sürülebilir. Yapılan araştırmalarda, bireylerin sahip olduğu kişilik özelliklerinin stresle başaçıkma stratejilerini etkilediği rapor edilmektedir (Parkes, 1986; Compas, Forsydhe \& Wagner, 1988; Hahn, 2000). Diğer yandan günümüzde daha çok kabul gören ve üzerinde araştırmalar yapılan stres teorileri, başaçıkma becerilerinin ve stres karşısında verilen tepkilerin genellikle bireysel farklılıklara göre değiştiği tezine dayanmaktadır (Burns \& D'Zurilla, 1999). Bu açıdan ele alındığında, sosyal becerinin önemli bir kişilik özelliği olarak stresle başaçıkmayı (duygu-odaklı ya da problemodaklı) etkileyen bir beceri olduğu ileri sürülebilir. Stres uzun vadeli etkileri açısından ele alındığında ise, sosyal beceri düzeyleri yüksek olan bireylerin stres kaynakları karşısında daha dirençli olabilecekleri ileri sürülebilir. Diğer yandan sosyal becerileri zayıf olan bireylerin; saldırgan davranışlar sergileme, madde kullanma, içe kapanma, intihar, depresyon ve diğer ruh hastalıkları ve çeşitli savunma mekanizmalarının kullanılması gibi yetersiz yöntemlere daha çok başvurabilecekleri söylenebilir.

Sosyal becerilerin günlük sosyal ilişkilerde yeterli düzeyde kullanılabilmesi diğer değişkenlerle birlikte uyum süreci açısından önemli bir değişken olarak karşımıza çıkmaktadır. Sosyal beceri düzeyleri yüksek olan bireylerin stres karşısında iletişim ve problem çözme becerilerini geliştirme, güvengen davranışlar sergileme, sosyal destekten yararlanma ve duygularını uygun biçimde paylaşabilmeyi öğrenme gibi yeterli yöntemlere daha çok başvurabileceklerini burada vurgulamak gerekir. Başka bir deyişle bu bireylerin stresle başaçıkmada daha etkili yollara başvurabilecekleri ifade 
edilebilir. Folkman \& Lazarus (1988), stresle başaçıkmada kişilik özelliklerinin önemli olduğunu belirtmektedir. $\mathrm{Bu}$ durum problem odaklı yaklaşım kullanılırken önemli bir değişken olarak devreye giren kişi-çevre ilişkisi açısından da benzer biçimde değerlendirilebilir. Yani sosyal beceri düzeyleri yüksek olan bireyler, stres kaynakları karşısında başaçıkma tepkileri sergilerken çevreyle ilişkilerini değiştirmede ve düzenlemede daha etkili olabilirler.

Mutluluk ve mutsuzluk konusunda yapılan araștırmalarda elde edilen bulguların da bu araştırmanın bulgularını desteklediği gözlenmektedir. Örneğin Arglyle ve Luo (1990), yüksek sosyal beceri düzeyi ile mutluluk, güvengenlik ve dışa dönüklük arasında pozitif yönde; depresyon ve mutsuzluk ile de negatif yönde bir ilişki olduğunu gözlemlemişlerdir. Bir diğer araştırmada Natvig, Albrektsen ve Qvarnstrom (2003) ise, stres düzeyleri yüksek olan ergenlerin kendilerini daha mutsuz hissettiklerini ve psikosomatik belirtilerin diğerlerine göre daha yüksek olduğunu saptamışlardır. Başka bir araştırmada Peterson, Park ve Seligman da (2005), kendini mutsuz hisseden bireylerin yaşamdan zevk alma, yaşamda anlam bulma ve insanlarla birlikte olma gibi konularda daha çok problem yaşadıklarını saptamışlardır. Benzer biçimde Abdel-Khalek de (2006) mutluluk ile iyimserlik, gelecekten umutlu olma, yüksek benlik saygısı, olumlu duygulanım durumu, dışa dönüklük ve kendini fiziksel ve ruhsal olarak sağlıklı hissetme durumu arasında anlamlı ilişkiler bulunduğunu saptamıştır. Yapılan diğer araştırmalarda ise mutluluk ile özgecilik (Post, 2005) ve benlik sayg1s1 (Cheng \& Furnham, 2004; Baumeister, Campbell, Krueper \& Vohs, 2003) arasında anlamlı ilişkiler bulunduğu rapor edilmektedir. Bu araştırmanın örnekleminde yer alan öğrencilerin \% 29'u (374 öğrenci) kendini mutsuz hissettiğini belirtmektedir. Yukarıda verilen araştırma bulgularına göre değerlendirildiğinde kendini mutsuz hisseden öğrencilerin yaşamdan haz alma ve anlam bulma, psikosomatik belirtiler, karamsarlık, umutsuzluk, depresyon ve benlik saygısı gibi değişkenler açısından da dezavantajlı durumda oldukları ileri sürülebilir.

Sonuç olarak, kendini mutsuz hisseden ve sosyal beceri düzeyleri düşük olan bireylerin stresle başaçıkmada diğer bireylere göre daha yetersiz oldukları ve psiko-sosyal desteğe daha çok ihtiyaç duydukları belirtilebilir. Araştırmada elde edilen bu sonuca dayalı olarak şu öneriler getirilebilir:

1. Sosyal beceri düzeyi düşük olan öğrencilere yönelik olarak sosyal beceri eğitimi programları uygulamaya koyulabilir.

2. Stresle başaçıkmada yetersiz yöntemleri daha çok kullanan öğrencilere yönelik olarak stresle başaçıkma eğitimi verilebilir.

3. Kendini mutlu ve mutsuz hisseden öğrencilerin, kişisel ve ailesel özellikleri üzerine karşılaştırmalı araştırmalar yapılabilir. Ayrıca üniversite ögrencilerinde mutluluğun ve mutsuzluğun nedenleri araştırılabilir. 


\section{KAYNAKLAR}

Abbott, P., \& Lewry, S. (1992). Front office: Procedures, social skills and management. Butterworth Heinemann, Oxford.

Abdel - Khalek, A. M. (2006). Measuring happiness with a single-item scale. Social Behavior and Personality, 34(2), 139-150.

Akkök, F. (2003). Illköğretimde sosyal becerilerin geliştirilmesi (anne-baba el kitabl). 3.Baskı. İstanbul: Özgür Yayınları.

Argyle, M. \& Lou, L. (1990). Happiness and social skills. Personality and Individual Difference, 11(12), 1254-1260.

Baltaş, A. ve Baltaş, Z. (2002). Stres ve başaçıkma yolları. İstanbul: Remzi Kitabevi.

Baumeister, R. F., Campbell, J. D., Krueger, J. I. \& Vohs, K. D. (2003). Does high self-esteem cause beter performance, interpersonal success, happiness, or healthier lifestyles? Psychological Science In The Public Interest , 4(1), 1-44.

Becker, R. E., Heimberg G. R., \& Bellack A. S. (1987). Social skills training treatment for depression, New York: Pergamon Press.

Begun, R. W. (1996). Ready - to - use. Social skills lessons and activities for grades 7 - 12. USA: Jossey - Bass A Wiley Imprint.

Burns, L. R., \& D'Zurilla, T. J. (1999). Individual differences in perceived information-processing styles in stress and coping situation: Development and validation of the perceived modes of processing inventory. Cognitive Therapy and Research, 23(4), 345-371.

Carver, C. S., Scheier, M. F. (1994). Situational coping and coping dispositions in a stressful transaction. Journal of Personality and Social Psychology, 66(1), 184-195.

Cheng, H. \& Furnham, A. (2004). Perceived parental rearing style, selfesteem and self-criticism as predictors of happiness. Journal of Happiness Studies, 5, $1-21$.

Cartledge, G. \& Milburn, J. F. (1992). Teaching social skills to children, USA: Pergamon Book Inc.

Compas, B. E., Forsydhe, C. J., \& Wagner, B. M. (1988). Consistency and variability in causal attributions and coping with stress. Cognitive Therapy and Research, 12(3), 305-320.

Crossley, A. \& Landridge, D. (2005). Perceived sources of happiness: A network analysis. Journal of Happiness Studies, 6, 107 - 135. 
Fontana, D. (1992). Problems in practice - social skills at work. Lecister: British Psychological Society.

Folkman, S., \& Lazarus, R. S. (1980). An analysis of coping in a middleaged community sample. Journal of Health and Social Behavior, 21, 219-239

Folkman, S., \& Lazarus, R. S. (1985). If it changes, it must be a process: Study of emotion and coping during three stages of college examination. Journal of Personality and Social Psychology, 50, 992 1003.

Folkman, S., \& Lazarus, R. S. (1988). Coping as a mediator of emotion. Journal of Personality and Social Psychology, 54(3), 466-475

Folkman, S., \& Lazarus, R. S., Gruen, R. J., \& DeLongis, A. (1996). Appraisal, coping, health status, and psychological symptoms. Journal of Personality and Social Psychology, 50(3), 571-579.

Fox, C. L., \& Boulton, M. J. (2005). The social skills problems of victims of bullying: Self, peer and teacher perceptions. British Journal of Educational Psychology, 75, 313 - 328.

Giblin, L. (1995). Insan ilişkilerinde kendine güven ve güç elde etmenin yolları. 2.Baskı. Çev: Güpgüpoğlu, İ. İstanbul: Sistem Yayıncılık.

Grinde, B. (2002). Happiness in the perspective of evolutionary psychology. Journal of Happiness Studies, 3, 331 - 354.

Hahn, S. E. (2000). The effects of locus of control on daily exprosure, coping and reactivity to work interpersonal sressors: A diary study. Personality and Individual Differrences, 29(4), 729-748.

Hamarta, E. (2000). Üniversite ögrencilerinin yalnızlık ve sosyal beceri düzeylerinin ögrrencilerin özlük nitelikleri açısından incelenmesi. Konya: Selçuk Üniversitesi Sosyal Bilimler Enstitüsü Yayınlanmamış Yüksek Lisans Tezi.

Hargie, O., Sounders, C. \& Dickson, D. (1994). Social skills in interpersonal communication. Third Edition. U. S. A. : Routledge London \& New York.

Harman, J. E., Hansen, C. E., Cochran, M. E. \& Lindsey, C. R. (2005). Liar, liar: Internet faking but not frequency of use affects social skills, selfesteem, social anxiety and agression. Cyber Psychology \& Behavior, $8(1), 1-6$.

Huprich, S. K., Clancy, C., Bornstein, R. F. \& Nelson-Gray, R. O. (2004). Do dependency and social skills combine to predict depression? 
Linking two diatheses in mood disorders research. Individual Differences Research, 2(1), 2 - 16.

Karasar, N. (1986). Bilimsel araştırma yöntemi: Kavramlar, ilkeler, teknikler. Ankara: Bilim Kitap Kırtasiye Ltd. Şti.

Kelly, J. A. (1982). Social skills training: A pratical guide for interventios, New York: Springer Publication Company.

Lazarus, R. S., \& Folkman, S. (1984). Stress, appraisal, and coping. New York: Springer Publishing Company, Inc.

Natvig, G. K., Albrektsen, G. \& Qvarnstrøm, U. (2003). Associations between psychosocial factors and happiness among school adolescents. International Journal of Nursing Practice, 9, 166-175.

Parkes, K. R. (1986). Coping in stressful episodes: The role of individual differences, environmental factors, and situational characteristics. Journal of Personality and Social Psychology, 51(6),1277-1292.

Peterson, C., Park, N. K. \& Seligman, M. E. P. (2005). Orientations to happiness and life satisfaction: The full life versus the empaty life. Journal of Happiness Studies, 6, 25 - 41.

Post, S. G. (2005). Altruism, happiness, and health: It's good to be good. Internatioanal Journal of Behavioral Medicine, 12(2), 66 - 77.

Ptacek, J. T., Smith, R. E., \& Zanas, J. (1992). Gender, appraisal and coping: A longitudinal Analysis. Journal of Personality, 60(4), 747770 .

Riggio R. E. (1986). Assessment of basic social skills. Journal of Personality and Social Psychology, 51(3), 649-660.

Riggio R. E., Tucker, J. \& Coffaro, D. (1989). Social skills and empathy. Personality and Indivudual Differences, 10(1), 93 - 99.

Richter, J., \& Richter, G. (1991). Perceived parental rearing, depression and coping behavior: A pilot study in psychiatric patients. Social Psychiatry and Psychiatric Epidemiology, 26(2), 75-77.

Segrin, C. (2001). Social skills and negative life events: Testing the deficit stress generation hypothesis. Current Psychology: DevelopmentalLearning-Personality-Social, 20(1), $19-35$.

Spence, S. H. (2003). Social skills training with children and young people: Theory, evidence and practice. Child and Adolescent Mental Health, $8(2), 84-96$. 
Şahin, N. (1994). Stresle başaçıkma. Olumlu bir yaklaşım. Ankara: Türk Psikologlar Derneği Yayınları.

Şahin, N. H., ve Durak, A. (1995). Stresle başaçıkma tarzları ölçeği: Üniversite öğrencileri için uygulanması. Türk Psikoloji Dergisi, 10(34), $56-73$

Uz Baş, A. (2003). Illköğretim 4. ve 5. sinif ögrrencilerinin sosyal beceri ve okul uyumlar ile depresyon düzeyleri arasindaki ilişkinin incelenmesi. İzmir: Dokuz Eylül Üniversitesi Sosyal Bilimler Enstitüsü Yayınlanmamış Doktora Tezi.

Wilson, A. R. S. (2002). Developing social skills and self-esteem in children with special needs. Primary Educator, 8(3), 17 - 23.

Yüksel, G. (2000). Sosyal beceri envanteri el kitabl. Ankara: Asil Yayın Dağıtım. 